\title{
Małgorzata KANIEWSKA
}

IEiB WFCh UKSW

\section{Globalne przyczyny zmian klimatu i ich przewidywany wpływ na środowisko}

Klimat podlega ciągłym zmianom i wahaniom. Przyczyny tych zmian do tej pory nie zostały w sposób zadowalający wyjaśnione. W dzisiejszych czasach niezwykle popularnym zjawiskiem jest skupianie się tylko i wyłącznie na emisji gazów cieplarnianych, uważanych za główną przyczynę zmian klimatu. Niezwykle ważne wydaje się zwrócenie uwagi na wpływ stałej słonecznej, albedo, rozkładu lądów oraz mórz jako na czynniki, które również mają ogromy wpływ na klimat. W mojej pracy starałam się odpowiedzieć na pytania: czy zmiany klimatyczne obserwowane obecnie na świecie, takie jak występujące coraz częściej huragany, susze, fale upałów, wymieranie gatunków, to tylko etap przejściowy czy też trwała zmiana, do której musimy jak najszybciej zacząć się przystosowywać? W jakim stopniu za te zmiany odpowiedzialny jest człowiek?

Mówiąc o zmianach klimatu nie sposób jest pominąć podstawowych procesów klimatotwórczych, do których zaliczamy bilans cieplny (promieniowanie krótkofalowe Słońca, cechy charakterystyczne atmosfery ziemskiej, rozpraszanie i pochłanianie promieni słonecznych $\mathrm{w}$ atmosferze, albedo, promieniowanie długofalowe Ziemi i atmosfery, efekt cieplarniany), ogólną cyrkulację atmosfery, cyrkulację oceaniczną (El Niño, La Niña) oraz czynniki geograficzne. Kształtowanie się bilansu cieplnego poszczególnych powierzchni zależy od wielu czynników m.in. od promieniowania krótkofalowego pochłoniętego przez podłoże, położenia Słońca, natężenia promieniowania rozproszonego, promieniowania długofalowego Ziemi oraz atmosfery. Należy zwrócić również uwagę, że inaczej będzie wyglądał bilans cieplny powierzchni wody, a inaczej gleby. Trzeba pamiętać, że jakiekolwiek wahania, któregoś z tych czynników mogą powodować zakłócenia w bilansie, a co za tym idzie powodować zmiany klimatyczne na Ziemi.

Analizując zmiany klimatu trzeba szczególnie zwrócić uwagę na Słońce, jako na podstawowe źródło energii, które dociera do Ziemi, jak również i atmosfery. Istotnym faktem jest to, że promieniowanie słoneczne nie ponosi praktycznie żadnych strat w czasie przenikania przez przestrzeń kosmiczną. Dzięki tym właściwościom o ilości energii docierającej ze Słońca do powierzchni Ziemi, decyduje odległość pomiędzy tymi ciałami. Ten parametr to stała słoneczna, która jest jedną z ważniejszych wielkości fizycznych $\mathrm{w}$ klimatologii. W bilansie promieniowania Ziemia-atmosfera 
zajmuje ona kluczowe miejsce. Pojęcie "stała słoneczna" może być trochę mylące, gdyż wbrew swej nazwie nie jest to wielkość stała. Wartość stałej słonecznej podlega licznym wahaniom, które są powodowane m.in. ruchem Ziemi po orbicie eliptycznej, nachyleniem jej osi, cyklem plam na powierzchni Słońca. $Z$ tych powodów zmienia się ona w cyklu rocznym o ok. 3-4\%. Do wniosku, że strumień promieniowania słonecznego, który dociera do górnej granicy atmosfery ziemskiej nie jest wartością stałą, naukowcy doszli stosunkowo niedawno. Udało im się to dzięki prowadzeniu obserwacji plam słonecznych za pomocą satelitów. Wpływ stałej słonecznej na klimat jest bardziej zauważalny w zestawieniach sięgających kilkuset tysięcy lat niż jako efekt krótkoterminowy.

Obok hipotezy związanej z aktywnością Słońca możemy odnaleźć jeszcze wiele teorii dotyczących zmian emisji promieniowania i ich wpływu na klimat. Jedna $\mathrm{z}$ nich wiąże się z założeniem, że średnica Słońca zmienia się w cyklu co 11, 22, 76 lat. Wynikają $z$ tego przypuszczenia na temat zmian średniej globalnej temperatury przy powierzchni, zwaną też oscylacją Gillilanda. Możemy zaobserwować podobieństwo pomiędzy wykresami dotyczącymi liczby plam słonecznych a temperaturą na Ziemi w ciągu ostatnich 100 lat. Jednak dane te nie są już zadawalające, jeśli sięga się dalej w przeszłość. Naukowcy do hipotezy oscylacji Słońca, jak również teorii wpływu grawitacji wielkich planet na Słońce podchodzą dość sceptycznie. Potrzebna jest jeszcze duża ilość badań i obserwacji, by obalić lub potwierdzić, którąś z wymienionych wyżej teorii. ${ }^{1}$

Kolejną interesującą hipotezę, zwaną orbitalą teorią zmian klimatu, wysnuł w 1930 roku jugosłowiański naukowiec Milutin Milankovitch, który stwierdził, że kształt ziemskiej orbity, ruch Ziemi wokół własnej osi oraz kąt nachylenia osi Ziemi do płaszczyzny ekliptyki są przyczyną długotrwałych zmian klimatu. Parametry te ulegają ciągłym zmianom. „Milankovitch utrzymywał, że nachylenie osi ziemskiej zmienia się od $21,8^{\circ}$ do $24,4^{\circ}$ co 41 tysięcy lat (...) stwierdził również, że orbita Ziemi staje się mniej lub bardziej eliptyczna co 100 tysięcy i 43 tysiące lat oraz że okres w ciągu roku, kiedy Ziemia jest najbliżej Słońca, zmienia się co 23 tysiące lat."2Do teorii Milankovitcha podchodzono dosyć sceptycznie, jednak dane astronomiczne w niej zawarte, zostały porównane z okresowymi zmianami klimatu zachodzącymi w historii Ziemi i jak się okazało, nachodziły one na siebie.

Wydaje się, że nie należy bagatelizować wpływu naturalnych czynników na klimat. Naukowcem, przywiązującym dużą wagę do tego typu zależności jest klimatolog z Uniwersytetu Warszawskiego profesor Jerzy Boryczka. W swojej publikacji pt.: „Zmiany klimatu Ziemi”, będącej podsumowaniem dotychczasowej działalności badawczej, kładzie szczególny nacisk na wpływ czynników pochodzenia naturalnego na klimat. Twierdzi mianowicie, że „dopływ energii słonecznej do powierzchni Ziemi zależy przede wszystkim od stałej słonecznej, której zmienność warunkować będą wahania klimatu w przyszłym stuleciu."3

C.D. SChöNwIESE, Klimat i czlowiek, Warszawa 1997, 128.

B. Buckley, J.R. Colquhoun, P. Sullrvan, R. Whitaker, Pogoda, Warszawa 1998, 17.

3 J. BoryCZKA, Zmiany klimatu Ziemi, Warszawa 1998, 6. 
Podobnego zdania są naukowcy z Holandii i Hiszpanii, którzy w „Nature” zwracają szczególną uwagę na wpływ cyklicznych zawirowań w ruchu Ziemi wokół Słońca. Uważają oni, na podstawie badań skamieniałości różnych gatunków gryzoni, że to właśnie zmiany kształtu orbity oraz nachylenia osi obrotu Ziemi są odpowiedzialne za zmiany klimatu, a co za tym idzie również za wymieranie i narodziny nowych gatunków.

Oprócz stałej słonecznej, teorii Milankovitcha trzeba zwrócić uwagę na atmosferę ziemską, która jest układem dynamicznym, $w$ którym następuje ciągłe mieszanie się mas powietrza. Ma ona istotny wpływ na typy klimatów i rozmieszczenie ich na kuli ziemskiej. Niezmiernie ważnym jej składnikiem jest para wodna, która pełni istotną rolę w procesie wymiany ciepła. Kolejnym czynnikiem odgrywającym znaczącą rolę w procesach klimatotwórczych jest albedo. Jego zmiana uważana jest obok efektu cieplarnianego za jedną z głównych przyczyn zmian klimatu. Na wartość planetarnego albedo Ziemi wpływa obecność aerozoli atmosferycznych oraz sposób użytkowania powierzchni, do którego możemy zaliczyć również wylesianie. Następnym czynnikiem, mającym wpływ na bilans cieplny, ale według niektórych naukowców najważniejszym jest efekt cieplarniany (szklarniowy). Wokół tego pojęcia narosło wiele mitów. Uważany jest on za głównego sprawcę globalnego ocieplenia klimatu. Efekt cieplarniany to pochłanianie przez gazy absorbujące promienia długofalowego Ziemi, a następnie emitowanie przez nie promieniowania, które częściowo znowu powraca na Ziemię. Do najczęściej wymienianych gazów cieplarnianych zaliczamy: parę wodną, dwutlenek węgla, metan, ozon, podtlenek azotu, dwutlenek siarki, freony. Gazem odpowiadającym w $60 \%$ za efekt cieplarniany jest para wodna, której stężenie nie ulega znacznym wahaniom i działa ona stabilizująco na temperaturę atmosfery. Jednak gdybyśmy nie brali jej w ogóle pod uwagę przy efekcie cieplarnianym, to głównym jego sprawcą byłby dwutlenek węgla. Jednak ocena wpływu gazów cieplarnianych pochodzenia antropogenicznego na zmiany klimatu w skali globalnej jest niezwykle trudna. Kłopoty wynikają zarówno ze zbyt małej ilości wiarygodnych danych dotyczących emisji gazów przez poszczególne kraje, jak również ciężko jest oddzielić wpływ naturalnych czynników na wahania klimatu.

Mówiąc o zmianach klimatycznych trzeba wspomnieć o ogólnej cyrkulacji atmosfery, cyrkulacji oceanicznej i czynnikach geograficznych. Mechanizmy rządzące globalną cyrkulacją atmosfery należą do kluczowych problemów, którymi zajmuje się współczesna meteorologia i klimatologia. Uważa się, że odgrywa ona istotną rolę w procesach klimatotwórczych zachodzących na Ziemi. Dzieje się tak przez transport mas powietrza, które posiadają różne właściwości fizyczne. W dużej mierze ma na nią wpływ strefowość geograficzna, która $\mathrm{z}$ kolei przejawia się głównie w rozkładzie ciśnienia. Na globalną cyrkulację atmosfery wpływa nie tylko stopień nagrzania powierzchni planety, jednak bardzo istotnym faktem jest także istnienie siły Coriolisa. Cyrkulacja wód jest również zjawiskiem złożonym. Na jej przebieg ma wpływ wiele czynników, takich jak: przyciąganie Księżyca i Słońca, wiatry, temperatura, ciśnienie, gęstość, siła Coriolisa i siła tarcia. Powstaje ona $z$ tych samych przyczyn co cyrkulacja atmosferyczna, jest związana z nierównomiernym dopływem energii słonecznej. 
$\mathrm{Na}$ skutek znaczących różnic temperatury powstają wówczas prądy atmosferyczne i wodne. Oprócz prądów morskich istotną rolę w globalnej cyrkulacji oceanicznej odgrywa cyrkulacja termohalinowa. Występuje ona na skutek różnic gęstości wody, wywołanymi zmianami temperatury oraz zawartości soli morskiej. Ma ona charakter globalny, a jej zadaniem jest wymiana ciepła pomiędzy obszarami strefy równikowej a terenami okołobiegunowymi. Uważa się, że nawet niewielkie zmiany w cyrkulacji termohalinowej mogą wywołać duże zmiany klimatyczne, dzieje się tak ze względu na dużą pojemność oceanów. Czynniki geograficzne (szerokość geograficzna, ukształtowanie i pokrycie terenu, rozkład lądów i mórz oraz prądy morskie) również mają istotny wpływ na klimat. $Z$ szerokością geograficzną wiąże się podział na strefy klimatyczne Ziemi, z rozkładem lądów i mórz związane jest istnienie odmiennych warunków termicznych na określonych obszarach. To właśnie rozmieszczenie lądów i mórz wpływa w ogromny sposób na amplitudy temperatury powietrza, ilość opadów, wilgotność. Natomiast ukształtowanie i pokrycie terenu odgrywa istotną rolę na wartość albedo. Nie można także bagatelizować czynników związanych z działalnością człowieka, które szczególnie są zauważalne na terenach rozwiniętych miast (degradacja środowiska naturalnego, zanieczyszczenie) i mogą mieć wpływ na klimat terenów przyległych.

Dotychczasowy stan wiedzy na temat przyczyn zmian klimatu nie pozwala człowiekowi z całkowitą pewnością przewidzieć przebiegu zdarzeń następujących pod wpływem danych czynników i tym samym rzutujących na cały system klimatyczny. Liczne niepewności powodują, że rozpatrując zmiany klimatyczne, które mogą zachodzić w przyszłości, mówimy o nich jako o scenariuszach, a nie prognozach.

Obecnie notuje się już zmiany w ekosystemach, które są spowodowane wzrostem średniej temperatury na Ziemi. Dzieje się tak, gdyż tempo zachodzących zmian jest zbyt szybkie, w stosunku do możliwości adaptacyjnych biosfery. Listę gatunków, którym grozi wyginięcie można znaleźć w „Czerwonej Księdze Gatunków Zagrożonych”, publikowanej przez Światową Unię Ochrony Przyrody (The World Conservation Union IUCN). Publikacja z 2006 roku zawiera ponad 16000 gatunków, którym grozi zagłada. Życie części gatunków zagrożone jest $\mathrm{z}$ powodu kłusownictwa, inną grupę stanowią gatunki, które mogą wyginąć $z$ powodu zmian w środowisku naturalnym, wywołanych również zmianami klimatycznymi.

Obszarem, na którym zmiany klimatu budzą najwięcej kontrowersji jest Antarktyka. Jaki jest ich faktyczny wpływ na liczebność gatunków roślin i zwierząt, żyjących w wodzie, jak i na lądzie, ciężko jest ocenić. Dzieje się tak, gdyż badania tego terenu trwają dopiero 30 lat. „Nie ulega jednak wątpliwości, że w ciągu ostatnich 50 lat obserwujemy w Antarktyce Zachodniej wyraźną deglacjację utożsamianą przez wielu z globalnym ociepleniem klimatu. Lody szelfowe i lodowce się cofają, a dane meteorologiczne wskazują na systematyczny wzrost temperatury powietrza". ${ }^{4}$

4 A. TATUR, Zmiany ekosystemów morskich i lqdowych Antarktyki pod wplywem fluktuacji klimatycznych, Zmiany klimatyczne w Arktyce i Antarktyce w ostatnim pięćdziesięcioleciu XX wieku $i$ ich implikacje środowiskowe, Gdynia 2006, 1. 
Ciężko jest jednak ocenić czy zmiany zachodzące w populacjach morskich w Antarktyce, wywołane są wyłącznie zmianami klimatu. Trudność polega na tym, że nie można przecież nie uwzględniać działalności gospodarczej człowieka. Nie do końca wiadomo czy zmiany ekologiczne wywołane są wyłącznie ociepleniem klimatu czy też połowami niektórych gatunków. Następstwem obserwowanego ocieplenia klimatu na terenach Półwyspu Antarktycznego może być pojawienie się gatunków inwazyjnych, które mogą być wskaźnikami potwierdzającymi postępujące zmiany klimatu. Antarktyda to jednak obszar nadal mało poznany i nie prowadzone były dotąd na nim badania w kierunku zmian klimatycznych.

Do pewników możemy natomiast zaliczyć ogromny wpływ klimatu na procesy zachodzące w przyrodzie. Ocieplający się klimat wpływa na szybszy rozwój roślin, przyspiesza ich kwitnienie, co z kolei prowadzi do trudności w synchronizowaniu się gatunków. Ptakom coraz trudniej jest trafić na okres największego występowania gąsienic czyli podstawowego pokarmu. Przewiduje się, że zmiany klimatyczne wpłyną/ wpływają na zasięg występowania lęgowisk, szlaków wędrownych, na przeżywalność dorosłych osobników, a także czas przystępowania do lęgów. Część gatunków zaczęła się już dostosowywać do zmieniającego klimatu. Jak poradzą sobie gady, płazy czy ssaki pokażą kolejne lata. Prawdopodobnie części gatunków nie uda się odpowiednio przystosować do zmieniających się warunków środowiska.

Zmiany klimatu wywierają presję nie tylko na zwierzęta, ale także na rośliny, co z kolei wiąże się z produkcją rolną. Szacuje się, że obecnie obserwowane zmiany spowodują wydłużenie okresu wegetacji. Prognozuje się przesunięcie granic zasięgu występowania niektórych roślin uprawnych na północ oraz rozszerzenie możliwości uprawy roślin ciepłolubnych. Wyżej wymienione zjawiska $z$ całą pewnością są korzystne dla Polski, problemem może okazać się spadek areału ziemniaka, a także słabsze kiełkowanie nasion roślin motylkowych. Nie wiemy jednak dokładnie jak będzie kształtował się klimat w XXI wieku i dlatego ciężko jest przewidzieć czy zmiany w rolnictwie przyniosą więcej pozytywnych czy też negatywnych następstw. Niezwykle istotny wydaje się również problem wpływu zmian klimatu na ekosystemy leśne, dzieje się tak, gdyż pomiędzy zmianami klimatu a ekosystemami leśnymi istnieje sprzężenie zwrotne. Lasy mogą zarówno przyspieszyć lub spowolnić proces globalnego ocieplenia. Wiele zależy od prowadzonej w sposób trwały i zrównoważony gospodarki leśnej. Należy w istotny sposób uwzględnić w niej rolę lasów, jaką pełnią one $w$ ochronie klimatu.

Zmiany klimatu mają także szereg kompleksowych połączeń ze stanem zdrowia. Wiadomo jest, że zmiany te nie będą jednakowo odczuwane na wszystkich obszarach. Niektóre rejony są narażone na nie bardziej inne mniej. Wzrost temperatury otoczenia oraz wilgotności stwarzają sprzyjające warunki do rozwoju bakterii, grzybów, wirusów. Rozwój tych organizmów będzie zachodził szybciej nie tylko w środowisku przyrodniczym, które stanowią gleba, powietrze i woda, ale także w żywności i instalacjach klimatyzacyjnych. Światowa Organizacja Zdrowia prognozuje, że wystąpi nie tylko wzrost zachorowań na salmonellę, infekcje w rodzaju malarii, ale także nastąpi wzrost umieralności, zwłaszcza ludzi w podeszłym wieku. Kolejnym problemem 
może okazać się niedobór wody pitnej i dostęp do niej, a także niedobór żywności. Częściowo możemy zabezpieczyć się przed tymi problemami przestrzegając zasad higieny, przechowując żywność w odpowiednich miejscach, zabezpieczając źródła wody pitnej. Sprawą nie do przebrnięcia mogą okazać się czynniki ekonomiczne, które wielu biednym państwom nie pozwolą przygotować się i poradzić ze skutkami globalnego ocieplenia. Kolejny aspekt powiązany ze zmianami klimatu to podnoszenie się poziomu mórz i oceanów. Może on okazać się katastrofalny w skutkach. Prawdopodobnie najbardziej ucierpią mieszkańcy ubogich krajów, których tereny zostaną zalane. Problemem stanie się nie tylko brak miejsca do mieszkania, ale również brak wody pitnej, ze względu na zasolenie gruntów.

Każdy miesiąc przynosi nowe raporty, które opisują zmiany jakie mogą zajść na Ziemi pod wpływem zmieniającego się klimatu. Lawinowo przedstawiane są modele komputerowe, które mają ukazać nam wygląd naszej planety pod koniec XXI wieku. Nie w pełni znamy rolę jaką odgrywamy w procesach zachodzących na Ziemi oraz możliwość sterowania nimi. Zmiany klimatu to szeroko dyskutowany problem. Ludzkość stoi przed ogromnym wyzwaniem, jakim jest rozwiązanie tej kwestii. Wydaje się, że jedyną możliwością poradzenia sobie z tym problemem jest globalna współpraca wszystkich państw. Jednym ze sztandarowych haseł działań na rzecz ochrony klimatu jest ograniczenie emisji gazów cieplarnianych. Wśród wielu rozwijających się państw może to rodzić liczne obawy, do których mogą należeć: ograniczenie rozwoju gospodarczego, spadek efektywności energetycznej. Głównym celem przeciwdziałającym zmianom klimatu wydaje się wypracowanie przez każde państwo odpowiedniej polityki związanej z ochroną klimatu, która może okazać się optymalnym "narzędziem” w dbaniu o klimat. Żyjemy w XXI wieku i mimo znacznego postępu technicznego głównym źródłem energii jest węgiel kamienny i ropa naftowa, a przecież istnieją odnawialne źródła energii, wykorzystywane w tak niewielkim stopniu. Nawet jeżeli hipotezy dotyczące przyszłości klimatu na Ziemi okażą się nietrafione warto postawić na wzrost świadomości ekologicznej ludzi. Może przerysowane wizje naszego negatywnego wpływu na klimat przyczynią się do ograniczenia obiektywnie szkodliwych czynników nie dla klimatu lecz bezpośrednio na człowieka. 